\title{
Acceleration of curing period of pastrami manufactured from buffalo meat: II-Fatty acids, amino acids, nutritional value and sensory evaluation
}

\author{
By Hayam M.A. Ibrahim
}

Food Tecnology and Dairy Dept., National Research Center, Dokki, Cairo, Egypt.

\section{RESUMEN}

\begin{abstract}
Aceleración del período de cura del pastrami fabricado a partir de carne de búfalo: Il-Ácidos grasos, aminoácidos, valor nutricional y evaluación sensorial.
\end{abstract}

En relación a la aceleración del período de cura del pastrami (carne curada en seco) preparada a partir de carne magra de búfalo usando un tratamiento térmico $\left(\sim 71^{\circ} \mathrm{C}\right.$ internamente), los resultados indicaron que los valores de peróxido y ácido tiobarbitúrico (TBA) aumentaron con el envejecimiento. El porcentaje de ácidos grasos libres liberados fue del 1,21 después del tratamiento térmico y aumentó gradualmente hasta alcanzar 1,47 después de dejar secar durante 6 días a temperatura ambiente para su completa curación.

Los ácidos grasos saturados e insaturados principales en todas las muestras del pastrami fueron palmítico (16:0), oleico (18:1) y linoleico (18:2). La concentración de los tres principales ácidos grasos poliinsaturados identificados (linoleico, linolenico y araquidónico) fue mayor en las muestras curadas aceleradas que en las muestras control. La relación de los ácidos grasos insaturados:saturados fue similar tanto en las muestras de pastrami control $(1,27: 1)$ como en las muestras tratadas térmicamente $(1,28: 1)$. Resultados similares se encontraron para la relación aminoácidos esenciales totales (EAAS): aminoácidos totales (AAS). El índice de aminoácidos esenciales (EAAl) fue más alto para la muestra tratada térmicamente que para la muestra control, lo que prueba la mejor aceptación biológica de la muestra de pastrami curada aceleradamente. La relación de eficacia protéica (PER) de todas las muestras investigadas alcanzó más de 2,42 de caseína.

La evaluación sensorial de la muestra de pastrami procesada a una temperatura interna de $\sim 71^{\circ} \mathrm{C}$ fue para los panelistas de color atractivo, más sabrosa, de buenas características olfativas y más tierna que las muestras control que fueron preparadas y curadas durante 3 semanas sin usar el tratamiento térmico.

PALABRAS-CLAVE: Ácidos grasos - Aminoácidos - Carne de búfalo - Evaluación sensorial - Pastrami - Valor nutricional.

\section{SUMMARY}

Acceleration of curing period of pastrami manufactured from buffalo meat: II-Fatty acids, amino acids, nutritional value and sensory evaluation.

Upon accelerating the curing period of pastrami (dry cured meat) prepared from buffalo lean round muscles using heat treatment $\left(\sim 71^{\circ} \mathrm{C}\right.$ internally), the results indicated that: the peroxide and thiobarbituric acid (TBA) values increased with increasing the aging period. Percentage of the released free fatty acids was 1.21 after heat treatment and increased gradually to reach 1.47 after hanging in air at room temperature for drying and complete curing up to 6 days.

The major saturated and unsaturated fatty acids in all of the pastrami samples were palmitic (16:0), oleic $(18: 1)$ and linoleic (18:2) fatty acids. The main three identified polyunsaturated fatty acids (linoleic, linolenic and arachidonic) were of high percentages in the accelerated cured samples than in the control one. The ratio of the unsaturated: saturated fatty acids was similar in either the heat treated $(1.28: 1)$ and the control $(1.27: 1)$ pastrami samples. Similar findings were found for the ratio of total essential amino acids (EAAS): total amino acids (AAS). The Essential Amino Acids Index (EAAI) that possesses higher percentage for the heat treated sample than that for the control one proved the higher biological acceptance of the heat accelerated cured pastrami sample. The predicted protein efficiency ratio (PER) of all the investigated samples reached more than 2.42 of casein.

Sensory evaluation of the pastrami sample processed to an internal temperature of $\sim 71^{\circ} \mathrm{C}$ proved by the panelists to be of attractive color, more tasty, of good characteristic odor and more tender than the control samples which were prepared and cured for 3 weeks without using heat treatment.

KEY-WORDS: Amino acids - Buffalo meat - Fatty acids Nutritional value - Pastrami - Sensory evaluation.

\section{INTRODUCTION}

Pastrami is a traditional Middle East dry fermented beef product (Katsaras et al., 1996) and the cured meat as well as sausage are well known since ancient Egypt. New methods for curing large pieces of meats have been succeeded in greatly shortened the curing periods and perfected in yielding more desirable, more tender and flavorful products (Lucy et al., 1982).

Pastrami of cured buffalo meat that processed with 160, 120 and $80 \mathrm{ppm} \mathrm{Na} \mathrm{NO}$; as well as with 120 and $80 \mathrm{ppm} \mathrm{NaNO}_{2}+0.2 \%$ sorbic acid were examined by Salama and Khalafalla (1987) for its chemical, microbiological, sensory changes and thiobarbituric acid (TBA) values during curing. The different levels of $\mathrm{NaNO}_{2}$ and sorbic acid had no significant effect on sensory properties (color, flavour, tenderness); while a noticeable increase in TBA values after $48 \mathrm{~h}$ of curing was found, followed by a marked drop in TBA values; but remained within safety limits.

Changes in thiobarbituric acid, free fatty acids, and in the major identified fatty acids during curing ( 3 weeks at $25^{\circ} \mathrm{C}$ ) of pastrami sample manufactured from pre-aged and non-pre-aged beef meat have been reported by Somaya (1994). Free fatty acids tended to increase through curing of pastrami and TBA values proved to be lower within the tested 
pre-aged samples. Palmitic and stearic acids predominated as saturated fatty acids, while oleic and linoleic acids were the main unsaturated ones.

Decomposition of polyunsaturated fatty acids (PUFA) results in the formation of low molecular weight aldehydes, acids, and ketones. Concentrations of the aforementioned components are indicators of off-flavour development (Ang \& Lyon, 1990). On the other hand, Igene et al., (1985) and El-Maguid, (1993) proved that nitrite in the cure salts is responsible for the development of a delicate flavour in the produced pastrami by virtue of its antioxidant properties.

Moller et al. (1998) reported that enzymic degradation of amino acids in fermented meat products, due mainly to microbial action is thought to generate aroma compounds that contribute to flavour development. It has recently been proposed that, in cured meats L-leucine is the precursor of' 3-methylbutanol, a compound which imparts a bacon-like flavour.

In a previous work (Hayam, 1999), the acceleration of curing period (by heat treatment) of pastrami samples manufactured from buffalo meat has been described. Changes in $\mathrm{pH}$, titratable acidity, meat colour, $\mathrm{NaNO}_{2}$ residue and nitrogen fractions as well as bacteriological screening during aging and curing processes were studied. As a continuation, the aim of the present investigation was to follow the changes in free fatty acids, TBA and peroxide values within pastrami samples manufactured from buffalo meat. The identified fatty acids, amino acids, and nutritional characteristics i.e. Chemical score, essential amino acid index (EAAl), biological value (BV) and protein efficiency ratio (PER) and organoleptic properties of the pastrami manufactured from cured buffalo meat, using heat treatment $\left(\sim 71^{\circ} \mathrm{C}\right.$ internal) to accelerate curing period were evaluated and compared with those of a control sample manufactured using the traditional method of curing i.e the meat was cured for 3 weeks at room temperature $\left(\sim 25^{\circ} \mathrm{C}\right)$ without using heat treatment.

\section{MATERIALS AND METHODS}

\subsection{Materials}

The lean round muscles of buffalo meat used in manufacturing pastrami (dry cured meat) were purchased from El-Basatin Local slaughter house, Cairo Governorate.

\section{Salting, mixture of curing salts}

The lean round muscles of buffalo meat were separated, weighed and cracked surfacely with a knife to facilitate the penetration of the salting and
Table I

Salting mixture formula used for meat aging

\begin{tabular}{lc}
\hline \multicolumn{1}{c}{ Ingredients } & Quantity \\
\hline Meat & $20 \mathrm{~kg}$ \\
Sodium chloride & $3.0 \mathrm{~kg}$ \\
Ascorbic acid & $20 \mathrm{~kg}$ \\
Sodium nitrate & $18 \mathrm{~kg}$ \\
\hline
\end{tabular}

curing mixtures through the tissues. The samples were put on a stainless-steel racks and salting mixture was spread uniformally on their surfaces (Table I).

Each sample was wrapped with a sheet of cotton tissue, covered with a wooden plate and heavy weight was put upon it. The samples were left for 2 days at room temperature $\left(\sim 25^{\circ} \mathrm{C}\right)$ for draining, after which they were washed with tap water to remove salt excess and hanged overnight for drying.

Before achieving curing, it was considered to coat all of the surfaces of the samples by three layers of curing paste (Table II) which was formulated with the required quantities of water (adjusted experimentally) to form a soft paste. The samples were hanged for 1 $\mathrm{h}$ after each layer application.

After that, the samples were divided into two portions:

- The first portion was initially heated in an electric oven at $82^{\circ} \mathrm{C}$ for $1 \mathrm{~h}$ after which $88^{\circ} \mathrm{C}$ was applied until the internal temperature reached $\sim 71^{\circ} \mathrm{C}(\sim 15 \mathrm{~min})$. The product was then hanged in air for 6 days at room temperature $\left(\sim 25^{\circ} \mathrm{C}\right)$ to complete curing and drying processes. The internal temperature of the samples was recorded using an Electronic Thermometer (AMA-DIGT, having a range from $35-500^{\circ} \mathrm{C}$ ).

- The second portion was subjected to the traditional curing method i.e. the product was hanged directly in air at room temperature

Table II

Curing paste formula

\begin{tabular}{lc}
\hline \multicolumn{1}{c}{ Items } & g/kg meat \\
\hline $\begin{array}{l}\text { Salt and curing agent } \\
\text { (salting mixture) }^{*}\end{array}$ & 20 \\
Paprika & 90 \\
Fenugreek & 90 \\
Wheat flour & 04 \\
Galic (fresh) & 180 \\
\hline
\end{tabular}

* As described in Table I. 
$\left(\sim 25^{\circ} \mathrm{C}\right)$ for curing and drying up to 3 weeks without using heat treatment.

\subsection{Chemical analysis}

- Thiobarbituric acid (TBA) value and free fatty acids were determined as described by Pearson (1981).

- Peroxide value was assayed according to the A.O.A.C (1990).

- Fatty acid methyl esters were prepared as described by Vögel. (1975), and analyzed with a Pye-Unicam gas liquid chromatograph, series 104, model 64. The column was packed with $10 \%$ polyethylene glycol adipate (PEGA) on celite (100 - 120 mesh), and the chromatographic analysis of the samples was carried out under the following conditions: column temperature $190^{\circ} \mathrm{C}$, nitrogen, hydrogen and air flow rates were 30,33 and $330 \mathrm{ml} / \mathrm{min}$, respectively. A flame ionization detector (FID) was used in detection, injector $220^{\circ} \mathrm{C}$ and detector $200^{\circ} \mathrm{C}$.

- Amino acids analysis: after hydrolysis of the sample with $6 \mathrm{~N} \mathrm{HCl}$ at $110^{\circ} \mathrm{C}$ for $24 \mathrm{~h}$, the HPLC apparatus (Waters Assoc. USA) was used for identifying the amino acids of the tested samples (modified PICO-TAG method), according to Millipore Cooperative (1987), With respect to tryptophan, it was assayed spectrophotometrically by the method of Opienska et al., (1963).

- Chemical score was evaluated by the method of FAO (1970) using FAO/WHO/UNU reference protein pattern (1991).

- The essential amino acid index (EAAI) was calculated according to Oser (1959).

- Biological value (BV) was based on the equation recommended by Oser (1959).

Protein efficiency ratio (PER) was calculated from amino acid contents according to the recommendation of Alsmeyer et al. (1974).

\section{3. Sensory evaluation}

Ten panalists were asked to evaluate pastrami samples for color, taste, odor, and texture. The mean values for each parameter in the organoleptic analysis were subjected to statistical analysis according to procedures reported by McClave and Benson (1991).

\subsection{Statistical analysis}

The SAS computer program (1987) was applied using the P II; for measuring standard deviation (SD), standard error (SE) and degree of variance $(\mathrm{V})$.

\section{RESULTS AND DISCUSSIONS}

\section{1. Quality parameters of pastrami fats}

Changes in free fatty acids (FFA), peroxide and thiobarbituric acid (TBA) values were considered the main parameters of fat quality upon comparing pastrami samples within the aging period. Data given in Table III shows a noticeable increment in free fatty acids contents. The peroxide value as well as the TBA indicated a proportional relation with aging period. For instance, TBA was $0.15 \mathrm{mg}$ malonaldehyde $/ \mathrm{kg}$ fat and reached to 0.42 after 2 days of aging.

Percentage of the released free fatty acids after heat treatment $\left(\sim 71^{\circ} \mathrm{C}\right.$ internal) of pastrami sample was 1.12 and reached 1.47 after hanging the samples in air at room temperature $\left(\sim 25^{\circ} \mathrm{C}\right)$ up to 6 days for drying and complete curing.

The peroxide value was 2.95 meq $\mathrm{O}_{2} / \mathrm{kg}$ fat for the accelerated cured sample; whereas it was 3.89 after two days of hanging and 6.21 after 6 days of drying and complete curing.

The pattern of TBA value during heat treatment and after hanging of pastrami samples in air for 6 days was found to follow the same trend of peroxide value. It is important to mention that measuring of malonaldehyde is considered to be a major product of lipid oxidation. In addition, the FFA levels in the tested pastrami samples were higher during curing period i.e. the amount of FFA increased by raised temperature. Presumably, such pattern could be due to enhanced activity of the lipases present in the

Table III

Changes in free fatty acids, peroxide value, and thiobarbituric acid (TBA) of pastrami during processing

\begin{tabular}{lccc}
\hline \multicolumn{1}{c}{$\begin{array}{c}\text { Pastrami } \\
\text { Samples }\end{array}$} & $\begin{array}{r}\text { Free fatty } \\
\text { acids (\%) }\end{array}$ & $\begin{array}{c}\text { Peroxide value } \\
\left.\text { (meq } 0_{2} / \mathbf{k g}\right)\end{array}$ & $\begin{array}{c}\text { TBA (mg malon- } \\
\text { aldehyde/kg) }\end{array}$ \\
\hline Aging period & & & \\
At Zero time & 0.32 & 0.45 & 0.15 \\
After 1 day & 0.54 & 1.02 & 0.28 \\
After 2 day & 0.95 & 1.61 & 0.42 \\
Statistical analysis & & & \\
Standard error & 0.1818 & 0.3348 & 0.0857 \\
Degree of variance & 0.0992 & 0.3364 & 0.0220 \\
Standard deviation & 0.3150 & 0.5800 & 0.1484 \\
Curing period & & & \\
At $71^{\circ}$ C internal & 1.21 & 2.95 & 0.54 \\
After 2 days & 1.29 & 3.89 & 0.62 \\
After 4 days & 1.38 & 4.42 & 0.78 \\
After 6 days & 1.47 & 6.21 & 0.82 \\
Statistical analysis & & & \\
Standard error & 0.0562 & 0.6853 & 0.0661 \\
Degree of variance & 0.0126 & 1.8783 & 0.0175 \\
Standars deviation & 0.1124 & 1.3705 & 0.1322 \\
\hline
\end{tabular}


sample and/or to the development of the production of microbial lipase during curing period. These results were in accordance to Flores et al. (1985) and Stahnke (1995).

Statistical analysis within the parameters: standard error, degree of variance and standard deviation assured the efficiency of TBA values than peroxide values for evaluating pastrami quality during aging and curing.

\subsection{Fatty acids composition}

Table IV shows the saturated and unsaturated fatty acids of the investigated pastrami samples. After 2 days aging, fatty acids were higher than their corresponding values in both the control sample (cured without heat treatment and dried in air at room temperature $\sim 25^{\circ} \mathrm{C}$ for 3 weeks) and the pastrami sample cured and dried up to 6 days.

The major saturated, monounsaturated and polyunsaturated fatty acids in the samples were palmitic (16:0), oleic (18:1) and linoleic (18:2) respectively.

It is of importance to mention the opinion of Stahnke (1995) who reported that nitrite salts may lead to a decrease in the FFA levels either by inhibiting production of lipases and/or the microorganisms involved and/or by interfering with the lipases themselves. The individual fatty acids level could be affected in the same way.
The proportion of unsaturated/saturated fatty acids were too close in pastrami sample cured by heat treatment (1.28:1) and that of the control sample (1.27:1). This indicated that the total percentage of saturated fatty acids was less than that of the unsaturated (mono - \& poly); thus realizing the tendency for liberation of more saturated rather than unsaturated FFA. This tendency could have a positive effect in reducing the possibility of rancidity (Allen \& Foegending, 1981; Kim \& Labella, 1987). The aforementioned statistical parameters confirmed such trend due to the lower values of SD, S E and degree of variance.

Statistical parameters namely standard deviation, standard error and degree of variance showed the main following points:

- The identified saturated fatty acid $\mathrm{C}_{18: 0}$ possesses the highest values of the given statistical parameters.

- Within the monounsaturated fatty acids, oleic acid having the highest standard error ( 0.219) and standard deviation (0.379) values.

- Linoleic acid $\left(\mathrm{C}_{18: 2}\right)$ of the polyunsaturated fatty acids having the highest statistical parameters as seen in Table IV.

\subsection{Identification of Amino Acids}

Amino acid analysis given in Table $\mathrm{V}$ proved that Glutamic acid was the predominant one with 16.2, 15.46 and 15,23 g/16gN and Aspartic acid came in

Table IV

Identified fatty acids of the pastrami samples after two days aging and after curing for 6 days

\begin{tabular}{|c|c|c|c|c|c|c|}
\hline \multirow{2}{*}{$\begin{array}{l}\text { Identified } \\
\text { fatty acids } \\
(\%)\end{array}$} & \multirow{2}{*}{$\begin{array}{l}\text { After } 2 \text { days } \\
\text { aging }\end{array}$} & \multirow{2}{*}{$\begin{array}{l}\text { After curing } \\
\text { for } 6 \text { days }\end{array}$} & \multirow{2}{*}{$\begin{array}{l}\text { Control * } \\
\text { sample }\end{array}$} & \multicolumn{3}{|c|}{ Statistical parameters } \\
\hline & & & & $\begin{array}{c}\text { Standard } \\
\text { deviation (SD) }\end{array}$ & $\begin{array}{l}\text { Standard } \\
\text { error (SE) }\end{array}$ & $\begin{array}{c}\text { Degree of } \\
\text { variance (V) }\end{array}$ \\
\hline $\begin{array}{l}\text { Saturated fatty acids } \\
\text { Lauric }\left(\mathrm{C}_{12: 0}\right) \\
\text { Myristic }\left(\mathrm{C}_{14: 0}\right) \\
\text { Palmitic }\left(\mathrm{C}_{16: 0}\right) \\
\text { Stearic }\left(\mathrm{C}_{18: 0}\right) \\
\end{array}$ & $\begin{array}{r}0.18 \\
3.10 \\
24.60 \\
19.50 \\
\end{array}$ & $\begin{array}{r}0.1 \\
2.6 \\
24.8 \\
18.2 \\
\end{array}$ & $\begin{array}{r}0.1 \\
2.6 \\
24.7 \\
18.1 \\
\end{array}$ & $\begin{array}{l}0.046 \\
0.289 \\
0.100 \\
0.781\end{array}$ & $\begin{array}{l}0.027 \\
0.167 \\
0.058 \\
0.451\end{array}$ & $\begin{array}{c}2.133 \times 10^{-3} \\
0.083 \\
0.010 \\
0.610\end{array}$ \\
\hline Total & 47.38 & 45.70 & 45.50 & & & \\
\hline $\begin{array}{l}\text { Monounsaturated } \\
\text { Myristoleic }\left(\mathrm{C}_{14: 1}\right) \\
\text { Palmitoleic }\left(\mathrm{C}_{16: 1}\right) \\
\text { Oleic }\left(\mathrm{C}_{18: 1}\right)\end{array}$ & $\begin{array}{r}0.4 \\
3.2 \\
44.8 \\
\end{array}$ & $\begin{array}{r}0.4 \\
3.2 \\
44.2 \\
\end{array}$ & $\begin{array}{r}0.4 \\
3.1 \\
44.1 \\
\end{array}$ & $\begin{array}{l}-\overline{058} \\
0.379 \\
\end{array}$ & $\begin{array}{l}\overline{0} \\
0.033 \\
0.219 \\
\end{array}$ & $\begin{array}{c}- \\
3.33 \times 10^{-3} \\
0.143 \\
\end{array}$ \\
\hline Total & 48.4 & 47.8 & 47.6 & & & \\
\hline $\begin{array}{l}\text { Polyunsaturated } \\
\text { Linoleic }\left(\mathrm{C}_{18: 2}\right) \\
\text { Linolenic }\left(\mathrm{C}_{18: 3}\right) \\
\text { Arachidonic }\left(\mathrm{C}_{20: 4}\right)\end{array}$ & $\begin{array}{l}9.6 \\
0.9 \\
0.7 \\
\end{array}$ & $\begin{array}{l}9.5 \\
0.8 \\
0.6 \\
\end{array}$ & $\begin{array}{l}9.2 \\
0.7 \\
0.5 \\
\end{array}$ & $\begin{array}{l}0.208 \\
0.100 \\
0.100 \\
\end{array}$ & $\begin{array}{l}0.120 \\
0.058 \\
0.058 \\
\end{array}$ & $\begin{array}{l}0.043 \\
0.010 \\
0.010 \\
\end{array}$ \\
\hline Total & 11.2 & 10.9 & 10.4 & & & \\
\hline Unsaturated: Saturated & $1.26: 1$ & $1.28: 1$ & $1.27: 1$ & & & \\
\hline
\end{tabular}

* Control sample means the use of traditional method in curing, i.e. curing for 3 weeks at room temperature ( 25ㄷ) without heat treatment. 
Table V

Amino acids of Pastrami samples: control after two days aging, and after curing for 6 days

\begin{tabular}{|c|c|c|c|c|c|c|}
\hline \multirow{2}{*}{$\begin{array}{l}\text { Amino acids } \\
\mathrm{g} / 16 \mathrm{gN}\end{array}$} & \multirow{2}{*}{$\begin{array}{l}\text { After } 2 \text { days } \\
\text { aging }\end{array}$} & \multirow{2}{*}{$\begin{array}{l}\text { After curing } \\
\text { for } 6 \text { days }\end{array}$} & \multirow{2}{*}{$\begin{array}{l}\text { Control * } \\
\text { sample }\end{array}$} & \multicolumn{3}{|c|}{ Statistical parameters } \\
\hline & & & & $\begin{array}{c}\text { Standard } \\
\text { deviation (SD) }\end{array}$ & $\begin{array}{l}\text { Standard } \\
\text { error (SE) }\end{array}$ & $\begin{array}{c}\text { Degree of } \\
\text { variance }(\mathrm{V})\end{array}$ \\
\hline \multicolumn{7}{|l|}{$\begin{array}{l}\text { Essential amino acids } \\
\text { (EAAS) }\end{array}$} \\
\hline Lysine & 9.03 & 7.95 & 8.05 & 0.752 & 0.434 & 0.566 \\
\hline Isoleucine & 5.10 & 4.15 & 3.95 & 0.614 & 0.355 & 0.378 \\
\hline Leucine & 8.30 & 8.16 & 8.90 & 0.393 & 0.227 & 0.154 \\
\hline Methionine & 4.10 & 2.31 & 2.15 & 1.083 & 0.625 & 1.172 \\
\hline Phenylalanine & 4.20 & 3.56 & 3.41 & 0.419 & 0.242 & 0.176 \\
\hline Valine & 4.80 & 4.41 & 4.45 & 0.215 & 0.124 & 0.046 \\
\hline Threonine & 4.80 & 4.25 & 4.05 & 0.388 & 0.224 & 0.151 \\
\hline Tryptophan & 0.90 & 0.76 & 0.86 & 0.072 & 0.042 & $5.2 \times 10^{-3}$ \\
\hline Total (EAAS) & 41.50 & 35.55 & 35.82 & & & \\
\hline \multicolumn{7}{|l|}{$\begin{array}{l}\text { non essential amino } \\
\text { acids (non.EAAS) }\end{array}$} \\
\hline Histidine & 3.60 & 2.65 & 2.96 & 0.484 & 0.279 & 0.235 \\
\hline Arginine & 5.20 & 4.01 & 3.94 & 0.708 & 0.409 & 0.501 \\
\hline Aspartic & 9.50 & 9.15 & 9.30 & 0.176 & 0.101 & 0.031 \\
\hline Glutamic & 16.20 & 15.46 & 15.23 & 0.507 & 0.293 & 0.257 \\
\hline Serine & 4.20 & 4.25 & 4.15 & 0.050 & 0.029 & $2.5 \times 10^{-3}$ \\
\hline Proline & 3.60 & 3.25 & 3.35 & 0.180 & 0.104 & 0.033 \\
\hline Glycine & 4.40 & 3.86 & 4.05 & 0.274 & 0.158 & 0.075 \\
\hline Alanine & 6.10 & 5.65 & 5.55 & 0.293 & 0.169 & 0.086 \\
\hline Tyrosine & 3.80 & 2.85 & 3.30 & 0.475 & 0.274 & 0.226 \\
\hline Cystine & 1.10 & 0.82 & 0.99 & 0.141 & 0.081 & 0.019 \\
\hline Total (non - EAAS) & 57.70 & 51.95 & 52.82 & & & \\
\hline Total amino acids (AAS) & 99.20 & 87.50 & 88.64 & & & \\
\hline Total (EAAS): Total (AAS) & $1: 2.39$ & $1: 2.46$ & $1: 2.47$ & & & \\
\hline
\end{tabular}

$2^{\text {nd }}$ order in the three investigated samples. Leucine was in the third order $(8,16$ and $8.9 \mathrm{~g} / 16 \mathrm{~g} \mathrm{~N})$ respectively for both heat treated and control pastrami samples; meanwhile, lysine $(9.3 \mathrm{~g} / 16 \mathrm{gN})$ was in $3^{\text {rd }}$ order amino acid for the sample aged for 2 days.

It is worthy to note that the concentration of Threoninc, Serinc, Proline, Glycine, Phenylalanine, Valine, Arginine and Isoleucine were approximately similar in the heat treated and the control samples; i.e. their values being ranged from 3.25 to $4.45 \mathrm{~g} / 16 \mathrm{gN}$.

It was generally noted from the data presented in Table $\mathrm{V}$ that the profile of the most amino acids in the samples after aging for 2 days showed higher values than those of the control samples and samples which were heat treated and hanged up to 6 days in air at room temperature for drying and complete curing. Such trend could be explained by the release of some free amino acids during curing process; and also might be to the probable denaturation, coagulation and heat destruction effects on meat proteins (Ramadan, 1986).
The total amino acids of the control pastrami samples were found to be $88.64 \mathrm{~g} / 16 \mathrm{gN}$; while that value of the samples after 2 days aging and of the heat treated samples was 99.20 and $87.50 \mathrm{~g} / 16 \mathrm{~g} \mathrm{~N}$ respectively.

The ratio of total essential amino acids (EAAS): total amino acids (AAS) was similar for the control samples and for the heat treated samples which may indicate that their nutritive values were nearly the same. This conclusion could be confirmed after comparing the calculated statistical parameters which realized lower values for SD, SE and degree of variance.

The essential amino acid index (EAAI) was found to be more than $95 \%$ for the three investigated pastrami samples (Table VI), However, the percentage for pastrami samples prepared by the acceleration method was higher than that of the control. This could prove the higher acceptance of biological value of the heat treated pastrami samples. 
Table VI

Essential amino acids values, chemical scores and essential amino acid index (EAAI) of pastrami samples

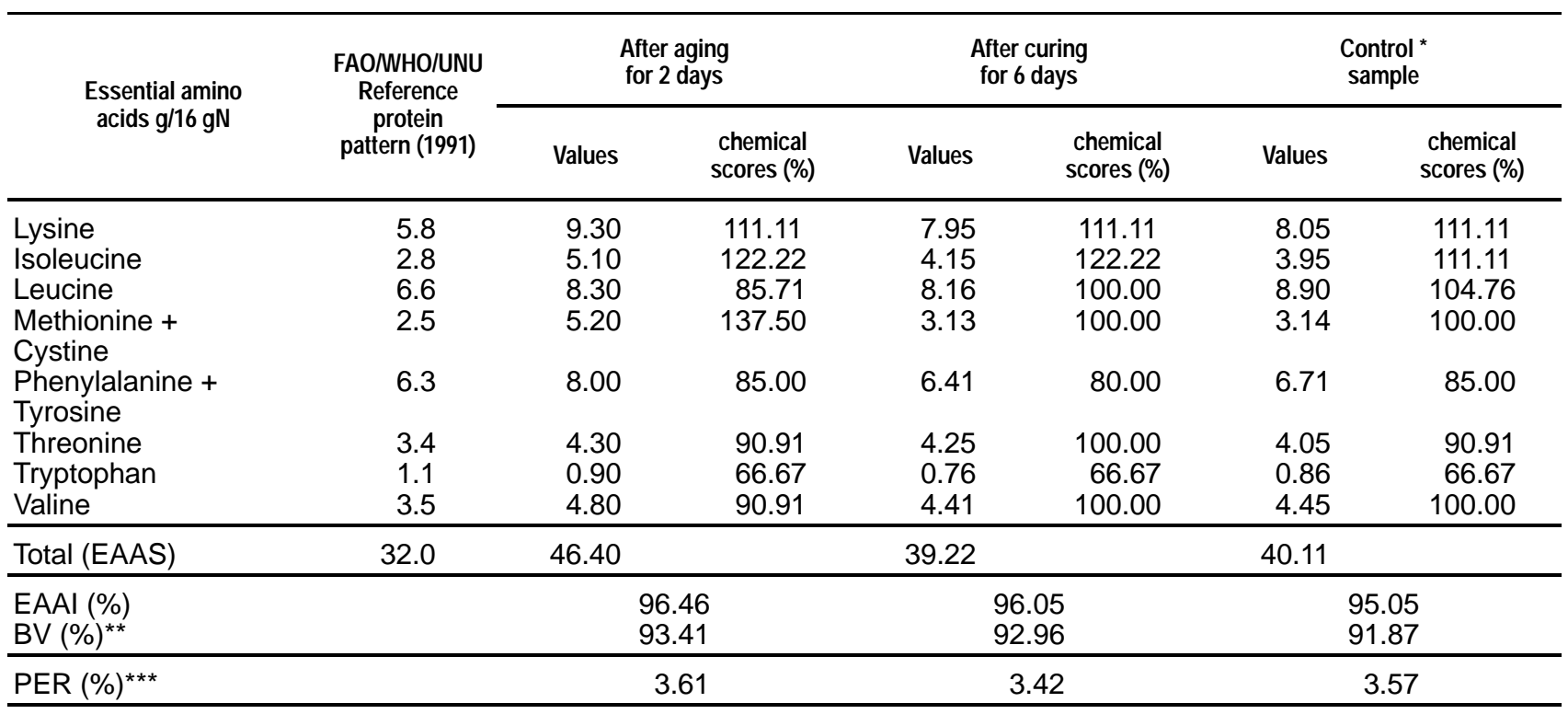

* Control sample means the use of traditional method in curing, i.e. curing for 3 weeks at room temperature without heat treatment.

** $\mathrm{BV}=$ biological value.

*** PER $=$ Protein efficiency ratio.

PER calculated from the equation: $-1.816+0.435$ (Methionine) +0.780 (Leucine) +0.211 (Histidine) -0.944 (Tyrosine) .

From the data presented in Table VI the tested pastrami samples possess higher biological value (BV) of more than $91 \%$, The slight differences between the BV values of the samples could be attributed to the release of slight concentration of free amino acids during the curing processes either as a result of heat treatment (to accelerate the curing period) or curing for long period without heat treatment.

With respect to the determination of protein efficiency ratio (PER) Satterlee et al., (1982) reported that while PER depending on rat bioassay remains the official procedure for protein quality determination, the calculated PER assays are recommended as alternative method for routine quality control of food and food ingredients. In the present work, it was attempted to predict the PER values of the studied pastrami samples using Alsmeyer's equation (1974) from which the predicted PER value of the pastrami sample prepared by the acceleration method was $3.42 \%$ which is very close to the control sample and more than $2.42 \%$ of casein.

\subsection{Sensory evaluation}

The influence of applying heat treatment $\left(\sim 71^{\circ} \mathrm{C}\right.$ internal) in order to accelerate pastrami curing period was sensory evaluated, and the data obtained for color, taste, odor and texture were compared with their corresponding values in pastrami samples processed by the traditional method. The data presented in Table VII cleared that there were significant differences $(P>0.01)$ between the pastrami samples manufactured by heat treatment to accelerate curing period method and by the traditional method of curing (i.e. cured for 3 weeks at room temperature $\left(\sim 25^{\circ} \mathrm{C}\right)$ without using heat treatment).

Pastrami samples processed by the suggested method (internal temperature of $\sim 71^{\circ} \mathrm{C}$ for accelerating its curing period) proved by the

Table VII

Average of sensory scores of the investigated pastrami samples

\begin{tabular}{lll}
\hline \multicolumn{1}{c}{ Sensory parameters } & \multicolumn{2}{c}{$\mathrm{I}^{\star}$ Pastrami samples } \\
\hline Color & $9.5^{\mathrm{a}}$ & $7 . \mathrm{I}^{\mathrm{b}}$ \\
Taste & $9.3^{\mathrm{a}}$ & $7.6^{\mathrm{b}}$ \\
Odor & $9.3^{\mathrm{a}}$ & $7.8^{\mathrm{b}}$ \\
Texture & $9.0^{\mathrm{a}}$ & $8.1^{\mathrm{b}}$ \\
\hline
\end{tabular}

$I^{*}$ Pastrami samples manufactured using heat treatment $\left(\sim 71^{\circ} \mathrm{C}\right.$ internal) to accelerated curing period up to 6 days.

$\|^{* *} \quad$ Pastrami samples manufactured by traditional method of curing i.e cured for 3 weeks at room temperature $\left(\sim 25^{\circ} \mathrm{C}\right)$ without using heat treatment.

a,b Means in column with no common superscript differ significantly $(P<0.01)$. 
panalists to be of attractive color, more tasty, of good characteristic odor and more tender than the traditional pastrami sample.

Accordingly it could be postulated that the applied heating procedure for accelerating curing period has a positive effects on the used sensory parameters. Hayam (1999) reported that there was higher chemical conversion percentage (i.e. improving color properties) in pastrami processed using heat treatment to internal temperature $\sim 71^{\circ} \mathrm{C}$ in order to shorten its curing time.

\section{CONCLUSION}

The effect of accelerating curing period by heat treatment $\left(\sim 71^{\circ} \mathrm{C}\right.$ internal) during pastrami manufacturing on peroxide and TBA values, fatty acids, amino acids, total EAAS: total AAS ratio, EAAI, BV and PER was studied and compared with their corresponding values in control pastrami samples manufactured and cured for 3 weeks without using heat treatment.

- The peroxide and thiobarbituric acid (TBA) values indicated a proportional relation with aging and curing periods.

- The total saturated fatty acids in the heat treated pastrami samples were approximately of the same percentages as those of the control sample; and a similar trend was observed for the total unsaturated fatty acids.

The unsaturated: saturated fatty acids ratio was too close in pastrami sample cured by using heat treatment and that of the control sample. This indicated that the total percentage of saturated fatty acids was less than that of the unsaturated; thus realizing the tendency for liberation of more saturated rather than unsaturated FFA. This could have a positive effect in reducing the possibility of rancidity.

- The percentage of EAAI for the heat treated pastrami samples was higher than that of the control samples. This could prove the higher biological acceptance of the heat treated samples, a pattern which was assured through the calculation of PER, which reached more than 2.42 of casein.

Thus, depending upon the above mentioned conclusions it could be stated that improving pastrami manufacturing via acceleration of the curing period by the applied heat treatment could be recommended.

\section{REFERENCES}

Allen C.E. and Foegeding, E.A. Food Technol. 35 (1981) 253.-C.F. Zalacain, I; Zapelena, M. J.; Astiasaran, I. and Bello, J.; Dry fermented sausages elaborated with lipase from candida cylindracea. Comparison with traditional formulations. Meat Sci. 40 (1995) 55-61.

Alsmeyer, H. R.; Cunningham, A. E. and Happich, M. L. Equations predict PER from amino acid analysis. Food Technology 28 (1974) 34.

Ang, C.Y.W. and Lyon, B.G. Evaluation of Warmed-over flavor during chill storage of cooked broiler breast, thigh and skin by chemical, instrumental and sensory methods. J.Food Sci. 55 (1990) 644-648, 673.

A.O.A.C. Official Methods of Analysis. Association of official Analytical Chemists, Arlington, Virginia, USA. (1990).

El-Maguid, N. Nitrite and nitrate levels in Egyptian pasterami. Meat Focus International 2(12) (1993) 554.

FAO. Amino acid contents of food and biological data on proteins. FAO Nutrition Studies 24 (1970).

FAO/WHO/UNU. FAO: food and Nutrition Paper 51. Food and Agriculture Organization of the United Nations, Rome. (1991).

Flores, J.P.; Nieto, P.; Bermell, S. and Miralles. M.C. Changes in lipids during slow and rapid maturation of dry cured ham and its relation to quality. Revista de Agroquímica / Tecnologia de Alimentos, 25(1) (1985) 117-124. CF. FSTA 17(10), 1985.

Hayam, MI. Acceleration of curing period of pastrami manufactured from buffalo meat: I. Chemical and Microbiological Properties. Sent for Publication, September, (1999).

Igene, J.O.; Yamauchi, K.; Peorson, A.M. and Gray, J.I. (1985): Mechanisms by which nitrite inhibits the development of Warmed-over flavor (WOF) in cured meat. Food Chem 18:1.

Katsaras, K.; Lautenschlaeger, R. and Boschkova, K. Physical-Chemical Processes in the production of Pasterma. Fleisch Wirtschaft; 76(2) (1996) 136-138, 141-142, 162.

Kim, R. S. and Labella, F. S. J. Lipid Res 28 (1987) 110CF. Zalacain, I; Zapelena, M. J.; Astiasaran, I. and Bello, J. Dry fermented sausages elaborated with lipase from candida cylindracea. Comparison with traditional formulations. Meat Sci. 40 (1995) 55-61.

Lucy, L.; Stephan, L. K. and Donald, K. T.- Ph.D. Food products formulary volume I Meats, poultry, fish, shellfish $2^{\text {nd }}$ Ed. The AVI publishing company, INC West port, Connecticut copyright (1982), printed in USA.

McClave, J. T. and Benson, P. G. Statistics for Business and Economics. Maxwell Macmillan International Editions. Dellen Publishing Company. USA. (1991).

Millipore Cooperative. Liquid chromatographic analysis of amino acids in food using a modification of PICO-TAG Method (1987).

Moller, J. K. S.; Hinrichsen, L. L.; Andersen, H. J. Formation of amino acid (L-Leucine, L-phenyl alanine) derived volatile flavour compounds by Moraxell a phenyl pyruvic and staphylococcus xylosus in cured meat model systems. International Journal of Food Microbiology 42 (1/2) (1998) 101-117.

Opienska, B.J.; Charezinski, M. and Berbe, C. A new rapid method of determining tryptophan. Anal. Biochem., 61 (1963) 69-76.

Oser, B. L. An integrated essential amino acid index for predicting the biological values of proteins. In Protein and Amino Acid Nutrition. (Alban. Ed.), Albanecee, A. A. P. 281, Academic Press, New York, N. Y. (1959).

Pearson, D. Pearson's chemical analysis of food $8^{\text {th }}$ Ed., Edinburgh, London, Melbourne and New York (1981). 
Ramadan, A. A. S. Effect of cooking methods and freezing storage on amino acids constituents of lamb meat. Egypt. J. Food Sci., 14(1) (1986) 23-29.

Salama N. A. and Khalafalla, G.M. Microbiological and chemical studies during basterma cured meat processing. Archiv Fuer Lebensmittel hygiene, 38(2) (1987) 57-61.

SAS: SAS/ STAT Guide for personal computers, Version 6 Ed., Cary, NC: SAS Institute Inc., (1987) PP. 1028.

Stahnke L. H. Dried sausage fermented with staphylococeus xylosas at different temps. And with different ingredient levels part I. Chemical and bacteriological data. Meat Sci. 41(2) (1995) 179-191.

Satterlee, L.D.; Kendrick, J.G.; Marshal. H.F.; Jewell, D. K.; Ali, R. A.; Hechman, M. M.; Steinka. H. F.; Larson, P.; Phillip, R. D.; Sarwar, G. and Slump. P. In vitro assay for predicting protein efficiency ratio as measured by rat bioassay: Collaborative study. J. Assoc. Offic. Anal. Chemists. 65(4) (1982) 738-809.

Somaya, M. A. Changes In amino acids and fatty acids during curing of pasterami samples manufactured from pre-aged and non pre-aged beef meat. Egypt. J. Appl. Sci., 9(11) (1994) 922-937.

Vögel, A. I. A text Book of practical Organic Chemistry. $3^{\text {rd }}$ ED., English Language Book Society and Longman Group Itd., (1975). 